\title{
COLLABORATION OF AN EPIDEMIOLOGIST AND A MUNICIPAL PUBLIC HEALTH OFFICER IN AN EPIDEMIOLOGICAL AND ENVIRONMENTAL INVESTIGATION OF LEGIONELLOSIS
}

\author{
HELENA ŠEBÁKOVÁ, RADIM MUDRA, IRENA MARTINKOVÁ, MARIE FIEDOROVÁ, \\ DANUŠE HANSLÍKOVÁ
}

SOUHRN

Je popsán př́pad legionelózy u staršího muže, který začal chřipkovými symptomy s následným zhoršováním a hospitalizací a při další progresi pokračoval umístěním na ARO fakultní nemocnice. Až zde byla diagnostikována legionelóza.

Epidemiologické šetření se zaměřilo na vodovodní vodu v bytě nemocného a odebrané vzorky potvrdily podezření na akviraci nákazy v místě bydliště. Izoláty z pitné a teplé vody obsahovaly bakterii Legionella pneumophila s denzitou $10^{2}-10^{3} \mathrm{KTJ} / 100 \mathrm{ml}$. Za jednoznačnou prríčinu kontaminace vody byl označen nedostatečný ohřev vody v nezaregulovaném teplovodním systému.

Účinným opatřením k nápravě byla termodezinfekce domovního vodovodního systému a chemodezinfekce pomocí instalovaného generátoru chlordioxidu.

Klicová slova: legionelózy, epidemiologické šetření, hygienický dozor

\section{SUMMARY}

Described is a case of legionellosis in an elderly male, that began with flu symptoms with consequent deterioration and hospitalization progressing to the IC unit. Only then was legionellosis diagnosed.

Epidemiological investigations were focused on tap water in the patient's flat; samples taken confirmed the suspicion. Isolates from drinking water as well as warm tap water contained Legionella pneumophila organisms at $10^{2}-10^{3} \mathrm{CFU} / 100 \mathrm{ml}$. The unequivocal cause of water contamination was the insufficient heating of the water in the unregulated hot water meins system.

An effective remedy was thermal disinfection of the water mains system in the building and chemical disinfection with the aid of an installed generator of chlorine dioxide.

Key words: legionellosis, epidemiological study, public health surveillance

http://dx.doi.org/10.21101/ hygiena.a1425

\section{Úvod}

Legionelózy z bytových komplexů nejsou často publikovány v literatuře. Za poslední 3 roky bylo popsáno 5 prípadů uvedených legionelóz, a to z Dánska, Německa, Itálie a Finska. Dle údajů NRL pro legionely ZÚ Ostrava bylo v ČR v letech 2007-2015 zaznamenáno 23 výskytů, z toho 16 sporadických a 7 clusterů.

Apartmánové domy, stavěné zejména v lukrativních lokalitách, představují nové trendy rekreace v České re- publice. Majitelé jsou zbaveni povinností běžných chalupářů (technická údržba stavby, zajištění tepla a teplé vody včetně zásobování tekoucí pitnou vodou). V současné době bývají ty to domy vybaveny centrální výrobou teplé vody. Většina bytů v apartmánových domech není užívána celoročně, byty zpravidla nejsou dále pronajímány. Tyto skutečnosti jsou predispozicí pro vznik biofilmů $\mathrm{v}$ rozvodech teplé vody $\mathrm{v}$ důsledku stagnace této vody a vytvoření optimálních podmínek pro pomnožování zejména mikroorganismu Legionella pneumophila. 
ve svém bytě, situovaném v rohu posledního patra šestipatrového domu.

Koncem roku 2014 byla nahlášena z apartmánového domu legionelóza u 69letého muže, pracujícího důchodce - podnikatele, který z počátku trpěl chřipkovými potížemi, suchým kašlem, slabostí, později vykašlával i krev. Tento stav však dával do souvislosti s antikoagulační léčbou. Po týdnu od objevení se prvních klinických příznaků došlo k progresi onemocnění, muž byl nalezen ve svém bytě a převezen RZP k hospitalizaci do místně př́slušné okresní nemocnice. Zde byly 2 krát mikrobiologicky vyšetřovány hemokultury, bylo provedeno virologické vyšetření. Odběr vzorků biologického materiálu ke stanovení legionel proveden nebyl. Postupně docházelo ke zhoršování dušnosti při oboustranné bronchopneumonii, pacient byl uměle ventilován, dostavila se ledvinová nedostatečnost. Zdravotní stav nemocného vyžadoval překlad na specializované pracoviště ARO FN, kde byla diagnostikována legionelóza. Původce byl diagnostikován ze sputa - L. pneumophila sg.1, ST 1, MAb OLDA. Za 31 dnů od prvních příznaků nemocný umírá pod obrazem sepse a multiorgánového selhání.

\section{Epidemiologické šetření v ohnisku nákazy}

Pracovníci protiepidemického odboru provedli po nahlášení pozitivního laboratorního výsledku (močový antigen) v rámci surveillance legionelóz epidemiologické šetření, včetně environmentálního. Cílem epidemiologického šetření bylo pátrání po zdroji nákazy, v případě legionelózy pátrání po rezervoáru nákazy, tj. prưkazu původce nákazy, který onemocnění vyvolal.

Na základě epidemiologické anamnézy bylo zjištěno, že $\mathrm{k}$ nákaze mohlo dojít během pobytu v zámoří, ale i po návratu do ČR v apartmánovém domě. Z důvodu nemožnosti komunikace s nemocným bylo epidemiologické šetření prováděno pouze s rodinnými př́slušníky. V jejich sdělení rovněž uvedli, že teplota teplé vody v apartmánu se téměř nelišila od teploty vody studené. Proto bylo rozhodnuto, že environmentální šetření bude provedeno nejdříve v domácnosti a dle výsledků bude př́ípadně uvažováno i o možné importované komunitní legionelóze. Pátráno bylo i po rizikových faktorech onemocnění, avšak kromě diabetes mellitus 2. typu na perorálních antidiabetikách, hypertenze, warfarinizace nebyly zjištěny žádné další.

Nemocný nepobýval ve spa či wellnes, aquaparku, poblíž fontán, ani v hotelu či lázních, jen se sprchoval

Epidemiolog při šetřeních používá veškeré dostupné odběrové metody, svou pozornost soustředí na možný přenos nákazy. V našem př́ípadě jsme se zabývali vodou, která přímo „teče na člověka“. Během epidemiologického šetření jsou vzorky jak teplé, tak studené vody odebírány způsobem odběru „první porce“, „druhá porce“ po minutě odpouštění; dále jsou prováděny stěry z vodovodních baterií, sprchových růžic, hadic apod. Epidemiologické šetření se provádí v místech pobytu nemocného během inkubační doby, tj. v bytě nemocného či v hotelu, případně ve zdravotnickém zařízení.

Výsledky tohoto šetření uvádíme v následující tabulce 1.

\section{Spolupráce odboru hygieny obecné a komunální s odborem protiepidemickým}

Z uvedených výsledků lze jednoznačně vyvodit, že centrální výroba teplé vody, díky již zmíněnému užívání bytových jednotek, nezaručuje dostatečnou teplotu na bateriích (sprchových, dřezových). Vyrovnaná teplota studené a teplé vody při odběru „první porce“" naznačuje nevhodně zhotovený rozvod vody v bytě, bez recirkulace. Navíc velmi vysoké počty legionel při odběru ,první porce“ studené vody nasvědčují, že se jedná o část vody vytlačené $z$ hadice ruční sprchy, která dlouhodobě (cca 1 měsíc) stagnovala $\mathrm{v}$ hadici s biofilmem masivně osídleným legionelami (obr. 1).

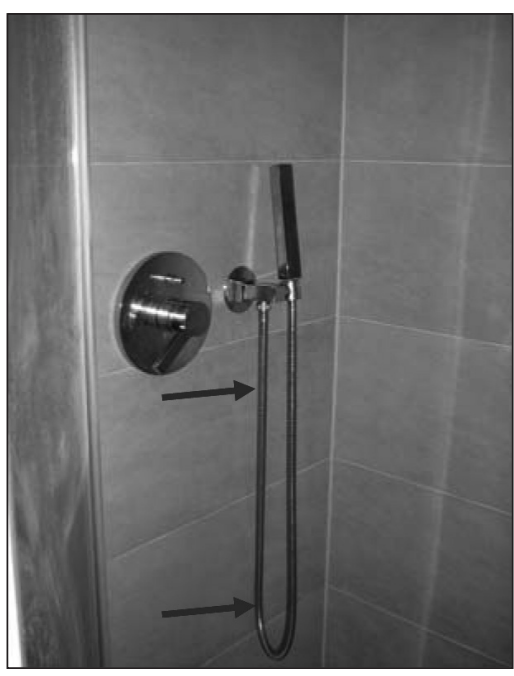

Obr. 1: Sprchová hadice s biofilmem osidleným legionelami.

Tab. 1: Výsledky odběrů epidemiologem ze dne 9. 12. 2014
\begin{tabular}{|l|c|c|c|}
\hline Místo odběru - Byt A, 6. NP & Druh vzorku & $\begin{array}{c}\text { Legionella spp. } \\
\text { KTJ/100 ml }\end{array}$ & $\begin{array}{c}\text { Teplota vody } \\
{ }^{\circ} \text { C }\end{array}$ \\
\hline Sprchový kout - sprcha - 1. porce & pitná* & 96000 & 23 \\
\hline Sprchový kout - sprcha - 1. porce & teplá & 24000 & 33 \\
\hline Sprchový kout - sprcha - po 1 min & teplá & 11000 & 22 \\
\hline Kuchyně - dřezová baterie - 1. porce & teplá & 7200 & 35 \\
\hline Kuchyně - dřezová baterie - po 1 min & teplá & 8 000 & L. pneumophila sg.1 \\
\hline Kuchyňská baterie & stěr & L. pneumophila sg.1 \\
\hline Sprcha - růžice & stěr & L. pneumophila sg.1 \\
\hline Sprcha - hadice & stěr & & \\
\hline
\end{tabular}

* ve skutečnosti se jedná o vodu stagnujici témèr 1 mèsic v hadici ručni sprchy

Identifikace izolátu z.vody: L. pneumophila sg.1, ST 1, MAb OLDA 
Tato skutečnost byla následně potvrzena prostudováním technické dokumentace, kdy bylo zjištěno, že si majitel apartmánu, oproti původnímu návrhu projektové dokumentace, zř́idil WC se sprchou u ložnice; vybudoval tedy cca 15 metrovou pŕípojku teplé a studené vody bez recirkulace.

Na základě výsledků uvedených v tabulce 1 lze konstatovat, že př́íčinou nevyhovujících nálezů je nedostatečný ohřev vody v nezaregulovaném teplovodním systému, který při nerovnoměrném obsazení bytů a používání teplé vody vytváří vhodné podmínky pro pomnožování legionel, $\mathrm{v}$ našem př́padě $\mathrm{v}$ denzitě až desetitisíců $\mathrm{K} T \mathrm{TJ} / 100 \mathrm{ml}$.

Odbor hygieny obecné a komunální byl vzhledem k výše uvedenému požádán odborem protiepidemickým o součinnost a provedení státního zdravotního dozoru nad kvalitou vyráběné teplé vody.

\section{Realizace státního zdravotního dozoru odborem HOK}

Pracovníci oddělení hygieny obecné a komunální zahájili tři dny po provedeném epidemiologickém šetření státní zdravotní dozor v objektu apartmánového domu. Kontrola kvality teplé vody výrobce byla provedena na vodovodních kohoutcích několika bytů v apartmánovém domě, kdy vzorky teplé vody byly odebírány v souladu s platnou legislativou, tzn. po 1 minutě, včetně měření teploty. Vzorky teplé vody byly rovněž odebrány v kotelně před ohřevem a za ohřevem. Vzorek studené pitné vody byl odebrán u vstupu do objektu, před ohřevem vody. Teplota studené pitné vody byla po její stabilizaci zaznamenána do protokolu, s následným odběrem vzorku vody.

Výsledky rozborů vody $\mathrm{v}$ rámci provedeného státního zdravotního dozoru jsou uvedeny v tabulce 2 .

Z výsledků vyplývá, že výrobce teplé vody, v rámci předběžné opatrnosti, provedl první opatření k eliminaci legionel v místě ohřevu (zvýšení teploty vody na výstupu z ohřevu na $68^{\circ} \mathrm{C}$ ). Voda přivedená zpět po recirkulaci apartmánovým domem měla teplotu (na zpátečce) $66^{\circ} \mathrm{C}$. V této souvislosti je zcela patrné, že teplovodní systém apartmánového domu nebyl dostatečně zaregulován, nebot' ve dvou bytech, po odpuštění teplé vody (1 minuta), dosáhla teplota vody pouze 48,9 a $58{ }^{\circ} \mathrm{C}$. Byty se nacházely na nezaregulovaných stoupačkách, kdy v teplé vodě byla prokázána denzita $10^{2}-10^{3}$ $\mathrm{K} T \mathrm{TJ} / 100 \mathrm{ml}$ legionel; přičemž byt zemřelého se nacházel na stejné stoupačce jako byt F, 2. NP (s průkazem legionel $10^{3} \mathrm{KTJ} / 100 \mathrm{ml}$ ).

Výrobce teplé vody v objektu apartmánového domu byl dne 30. 12. 2014 informován o nevyhovujících výsledcích rozborů teplé vody. Ve dnech 1. 1. 2015 - 2. 1. 2015 zajistil posouzení systému rozvodů teplé vody odbornou firmou, která navrhla jakým způsobem eliminovat legionely v tomto konkrétním př́padě. Jako jediné účinné řešení odborná firma navrhla chemodezinfekci (instalaci generátoru chlordioxidu na místě). Nicméně dne 7. 1. 2015 provedla účinnou termodezinfekci systému v celém objektu a následně dne 14. 1. 2015 generátor chlordioxidu instalovala (obr. 2).

Účinnost provedených opatření byla ověřena kontrolními odběry vzorků teplé vody v objektu apartmánového domu. Výsledky laboratorních analýz (nulové hodnoty), provedených Národní referenční laboratoří ZÚ Ostrava, potvrdily účinnost navrženého řešení.

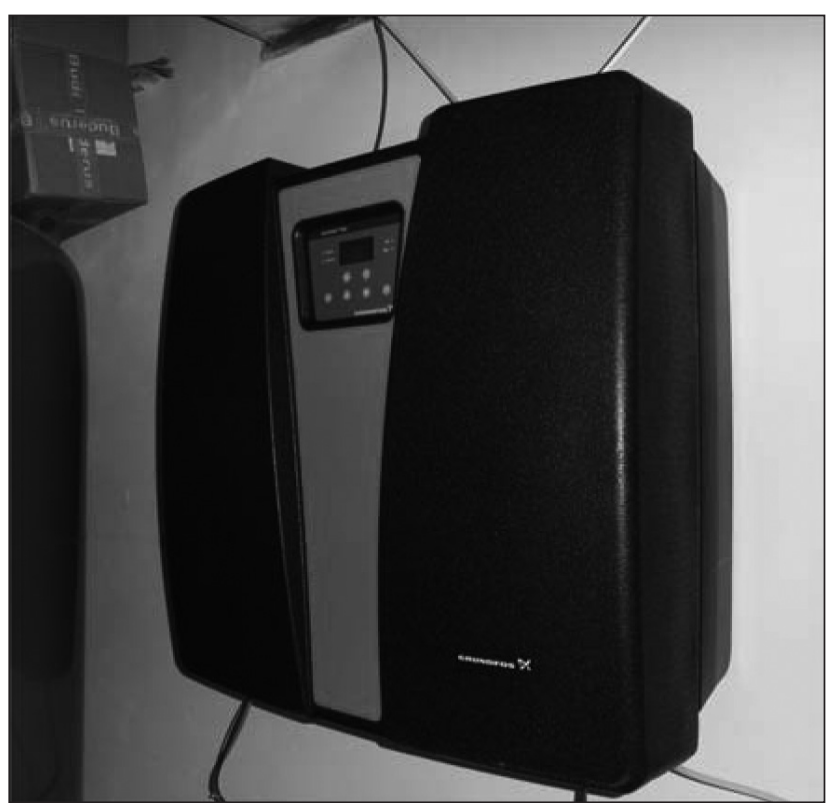

Obr. 2: Generátor chlordioxidu.

Tab. 2: Výsledky odběrů hygieny obecné a komunální ze dne 12. 12. 2014

\begin{tabular}{|l|c|c|c|}
\hline Místo odběru & $\begin{array}{c}\text { Legionella spp. } \\
\text { KTJ/100 ml }\end{array}$ & $\begin{array}{c}\text { Počty kolonií při 36,0 }{ }^{\circ} \mathrm{C} \\
\text { KTJ/ml }\end{array}$ & $\begin{array}{c}\text { Teplota vody } \\
{ }^{\circ} \mathrm{C}\end{array}$ \\
\hline kotelna - pitná & 0 & 6 & 9,3 \\
\hline kotelna výstup z ohřevu & 0 & 1 & 68,0 \\
\hline kotelna zpátečka & 0 & 1 & 66,0 \\
\hline Byt B, 6. NP & 0 & 2 & 62,0 \\
\hline Byt C, 6. NP & 110 & 51 & 48,9 \\
\hline Byt D, 5. NP & 0 & 0 & 62,0 \\
\hline Byt E, 5. NP & 0 & 0 & 63,6 \\
\hline Byt F, 2. NP* & 2100 & 9 & 58,0 \\
\hline
\end{tabular}

* byt $\mathrm{F}$ je na stejné stoupačce jako byt $A$ zemrelébo

Identifikace ǐolátu z. vody: L. pneumophila sg.1, ST 1, MAb OLDA věetně sekvenace (metodou SBT), dle platné metodiky doporučení EWGLI (European Working Group of Legionella Identification) 
V našem případě laboratorní rozbory vody prokázaly jasnou shodu mezi kmeny legionel z teplé vody a klinic-

Nové trendy ve zpo̊sobu užívání apartmánových domů k rekreaci přinášejí zvýšená zdravotní rizika mikrobiologického osídlení rozvodů teplé vody.

$\mathrm{V}$ rámci prováděného státního zdravotního dozoru, ve spojitosti s došetřováním legionelóz, nestačí zjišt'ovat pouze denzity Legionelly spp. (stanovený limit). Nutno dourčovat kmeny, subtypy, alelický profil - na základě uvedeného posoudit virulenci, která je vodítkem pro analýzu rizika OOVZ.

$\mathrm{V}$ rámci diferenciální diagnostiky zejména komunitních pneumonií je nutno pomýšlet i na legionelózu. U pneumonie je nasazována empirická antibiotická léčba, př́padně dochází k její změně za makrolidovou řadu. Pokud se jedná o odběr biologického materiálu, ve většině př́ipadů se ke stanovení diagnózy využívá vyšetření močového antigenu (UAg). Toto vyšetření je levné a rychlé a klinikovi plně postačuje pro další léčbu. Z epidemiologického hlediska je nezbytné k průkazu rezervoáru nákazy kultivační vyšetření a následné dourčení kmene až na molekulární úroveň. kého izolátu; ve stěrech ze sprchové hadice a kohoutků byly prokázány čisté kultury původce nákazy.

Díky spolupráci epidemiologů a komunálních hygieniků bylo objasněno ohnisko nákazy a nastavena účinná protiepidemická opatření. Tato opatření vedla k minimalizaci rizika akvirace nákazy aplikováním kontinuální chemické dezinfekce. Výsledkem byly nálezy nulových hodnot legionel v teplovodním systému apartmánového domu.

Došlo do redakece: 18. 1. 2016

Prijato ke tisku: 20. 1. 2016

MUDr. Helena Šebáková, Krajská bygienická stanice se sídlem v Ostravě $\mathrm{Na}$ Bélidle 7

70200 Ostrava E-mail:helena.sebakova@khsova.cr. 